\title{
MENINGKATKAN KEMAMPUAN BERPIKIR KRITIS DAN HASIL BELAJAR SISWA MENGGUNAKAN PENDEKATAN PROBLEM POSING BERORIENTASI HOTS (HIGHER ORDER THINKING SKILL) PADA MATERI HIDROLISIS GARAM
}

\section{Improving Student Critical Thinking Ability And Learning Outcomes using Problem Posing Approach with HOTS (Higher Order Thinking Skill) On Salt Hydrolysis Material}

Aulia Kasih*, Atiek Winarti

Program Studi Pendidikan Kimia FKIP Universitas Lambung Mangkurat, Jl. Brigjend. H. Hasan Basry Banjarmasin 70123 Kalimantan Selatan Indonesia *email: auliakimia2013@gmail.com

\begin{abstract}
Abstrak. Penelitian ini tentang penggunaan pendekatan pembelajaran problem posing berorientasi HOTS pada materi hidrolisis garam. Penelitian ini bertujuan untuk mengetahui aktivitas guru dan siswa, kemampuan berpikir kritis dan hasil belajar kognitif siswa. Rancangan penelitian ini adalah penelitian tindakan kelas (PTK). Tiap siklus terdiri dari tahap perencanaan, pelaksanaan tindakan, observasi dan evaluasi, serta analisis dan refleksi. Subjek penelitian ini adalah siswa kelas XI IPA 2 SMA PGRI 6 Banjarmasin dengan jumlah siswa 39 orang. Data dikumpulkan melalui teknik observasi, tes kemampuan berpikir kritis, dan tes hasil belajar kognitif. Data dianalisis dengan teknik analisis deskriptif kuantitatif dan analisis kualitatif. Hasil penelitian ini menunjukkan bahwa (1) aktivitas guru meningkat dengan kategori cukup baik pada siklus I menjadi baik pada siklus II. (2) Aktivitas siswa meningkat dengan kategori cukup aktif pada siklus I menjadi aktif pada siklus II. (3) Kemampuan berpikir kritis siswa meningkat dengan kategori cukup kritis pada siklus I dan kritis pada siklus II. (4) Hasil belajar kognitif siswa meningkat secara klasikal dengan kategori kurang baik pada siklus I menjadi cukup baik pada siklus II.
\end{abstract}

Kata kunci: berpikir kritis, problem posing, HOTS (Higher Order Thinking Skill), hidrolisis garam

\begin{abstract}
This research has use problem posing approach with HOTS (higher order thinking skill) model on salt hydrolysis materials. This study aims to know teacher and student activity, critical thinking ability and improve HOTS learning outcomes. The study used a classroom action research (CAR) with 2 cycles. Every cycles consisting of stages planning, action execution, observation and evaluation, analysis and reflection. The subjects of the study were students of class XI IPA 2 SMA PGRI 6 Banjarmasin with 39 people. Data were collected through observation techniques, critical thinking ability test and cognitive test results. Data analysis with quantitative descriptive analysis techniques and qualitative analysis. The results reaserch showed that (1) teacher activity increase with category well-enough on first cycles to well on second cycles. (2) student activity increase with category active-enough on first cycles to active on second cycles. (3) ) student critical thinking abilty increase with category critical-enough on first cycles to critical on second cycles (4) results of student learning in the cognitive increased with category less-well on first cycles to enough-well on second cycles.
\end{abstract}

Keywords: critical thinking, problem posing, HOTS (Higher Order Thinking Skill), salt hydrolysis

Copyright @ JCAE-Jurnal Tugas Akhir Mahasiswa, e-ISSN 2613-9782

Program Studi Pendidikan Kimia FKIP Universitas Lambung Mangkurat 


\section{PENDAHULUAN}

Lemahnya proses pembelajaran merupakan salah satu masalah dalam dunia pendidikan. Siswa kurang didorong untuk mengembangkan kemampuan berpikir. Siswa hanya diarahkan untuk menghafal informasi. Siswa dipaksa untuk menghafal dan menumpuk berbagai informasi tanpa memahami dan menghubungkan dengan kehidupan sehari-hari. (Sudarman, 2007). Siswa harus didorong untuk merumuskan dan memecahkan masalah, berpikir analitik dan kerja sama. Proses pembelajaran yang dapat mendorong peserta didik hal tersebut adalah proses pembelajaran yang berpusat pada siswa (student centered active learning).

Berdasarkan hasil observasi selama pelaksanaan Praktik Pengalaman Lapangan (PPL) di SMA PGRI 6 Banjarmasin, pada pembelajaran guru masih menjadi pusat dalam proses pembelajaran (teacher centered learning). Guru lebih dominan dalam proses pembelajaran oleh karena itu siswa kurang aktif dan hanya menerima apa yang disampaikan oleh guru. Kurangnya kemampuan berpikir kritis siswa saat kegiatan pembelajaran berlangsung dapat dilihat pada saat kegiatan pembelajaran ketika guru menyajikan suatu masalah siswa hanya diam saja dan sebagian siswa saja yang mau berpikir untuk menemukan atau memecahkan permasalahan. Permasalahan ini berdampak pada ketuntasan siswa, dapat dilihat pada ketuntasan siswa SMA PGRI 6 Banjarmasin tahun 2016 yang mencapai nilai kriteria ketuntasan minimal (KKM) yaitu 75 pada materi hidrolisis garam hanya 54,5\%. Disamping itu dari pihak guru pengajar tidak pernah menerapkan pembelajaran Problem Posing, apalagi pembelajaran yang berorientasi Higher Order Thinking Skill (HOTS). Studi pendahuluan pada siswa kelas XI IPA 2 SMA PGRI 6 Banjarmasin dengan memberikan soal tes gaya-gaya berpikir kreatif-kritis menggunakan instrumen gaya-gaya berpikir kreatif-kritis Yanpiaw diperoleh 63\% siswa belum mencapai kritis dan $37 \%$ berpikir kritis.

Nurina dan Retnawati (2015) pengembangan kemampuan berpikir tingkat tinggi siswa akan menghasilkan siswa yang handal dalam menyusun strategi dalam menyelesaikan masalah. Untuk mengatasi masalah tersebut maka dibutuhkan pendekatan pembelajaran berbasis masalah. Salah satu referensi pendekatan pembelajaran yang dapat digunakan untuk meningkatkan kemampuan pemecahan masalah siswa adalah pendekatan pembelajaran problem posing. Anto, dkk (2013) mengemukakan dengan pendekatan problem posing adalah siswa aktif dalam membuat pertanyaan-pertanyaan sehingga mampu merangsang kemampuan berpikir kritis siswa. Wawasan siswa akan bertambah dari pertanyaan-pertanyaan yang dibuat oleh perorangan ataupun kelompok sehingga proses pembelajaran di kelas cenderung mengasikkan dan kejenuhan siswa berkurang karena siswa bebas mengemukakan permasalahan dan menemukan pemecahan permasalahan tersebut.

Pembelajaran kimia di SMA terdiri dari beberapa pokok bahasan salah satunya adalah hidrolisis garam. Materi hidrolisis garam meliputi pengertian hidrolisis garam, macam-macam hidrolisis garam, dan perhitungan $\mathrm{pH}$ dari garam yang terhidrolisis tersebut. Materi tersebut memuat banyak konsep prasyarat yang harus dikuasai siswa antara lain persamaan reaksi, sifat-sifat zat, kesetimbangan kimia, konsentrasi (molaritas) dan teori asam-basa Bronsted-Lowry. Kesulitan belajar siswa rata-rata terletak pada reaksi-reaksi dalam hidrolisis garam dan pada perhitungannya, mereka dituntut untuk menjawab soal-soal yang berhubungan dengan pemahaman konseptual maupun algoritmik.

Permasalahan-permasalahan di atas dapat diatasi dengan tindakan yang dapat memperbaiki kualitas pembelajaran agar prestasi belajar siswa meningkat. Tindakan yang dapat dilakukan yaitu melalui Penelitian Tindakan Kelas (PTK) atau Classroom Action Research (CAR). Tindakan ini bertujuan untuk menyelesaikan masalah 
melalui tindakan (Suharsimi, 2015). Berbagai persoalan pembelajaran dan peningkatan kemampuan guru dalam mengelola proses pembelajaran dapat dilakukan pada penelitian ini (Mulyasa, 2009).

Hasil penelitian Anto, dkk (2013) mengemukakan bahwa dengan penerapan pembelajaran problem posing dapat meningkatkan keterampilan berpikir kritis siswa. Rerata kemampuan berpikir kritis siswa $43,13 \%$ pada pra siklus, meningkat menjadi $55,31 \%$ pada siklus I dan meningkat lagi $71,52 \%$ pada siklus II. Widodo dan Kadarwati (2013) menyatakan bahwa dari hasil penelitiannya diperoleh hasil belajar siswa meningkat menjadi $73,84 \%$, siswa yang telah menguasai materi sebanyak $96,87 \%$ dan skor aktivitas $83,81 \%$.

\section{METODE PENELITIAN}

Penelitian dilaksanakan dengan menggunakan rancangan penelitian tindakan kelas (classroom action research) yang terdiri dari tahap perencanaan, tindakan, observasi dan evaluasi, dan refleksi yang dilaksanakan pada 18 April hingga 5 Mei 2017. Setiap siklus dilaksanakan dalam 2 kali pertemuan dan 1 kali pertemuan dilaksanakannya tes kemampuan berpikir kritis dan hasil belajar kognitif, sehingga untuk kedua siklus terdapat 6 kali pertemuan. Setiap kali pembelajaran digunakan pendekatan problem posing berorientasi HOTS terdiri atas 2 dan 3 jam pelajaran (2 dan 3x 45 menit). Selama proses pembelajaran yang dilaksanakan dalam dua siklus ini, kemampuan berpikir kritis dan hasil belajar kognitif HOTS siswa pada materi hidrolisis garam dapat ditingkatkan. Selain itu, kegiatan observasi juga dilakukan untuk mengumpulkan informasi tentang proses kegiatan pembelajaran didalam kelas yaitu aktivitas guru dan aktivitas siswa selama pembelajaran berlangsung. Penelitian dilakukan dikelas XI IPA 2 SMA PGRI 6 Banjarmasin yang beralamat di Jalan Belitung Darat Simpang Anem Komplek Antaluddin, RT. 29 No. 26, Banjarmasin. Jumlah siswa 39 orang terdiri dari 11 orang laki-laki dan 28 orang siswa perempuan dengan tingkat kemampuan dan daya serap siswa bervariasi. Objek dalam penelitian ini berupa sesuatu yang ingin dicapai yaitu aktivitas guru dan siswa, kemampuan berpikir kritis siswa dan hasil belajar kognitif HOTS. Instrumen dalam penelitian ini terdiri atas instrumen tes yaitu tes kemampuan berpikir kritis dan hasil belajar kognitif HOTS dan instrumen non-tes yaitu lembar penilaian observasi aktivitas guru dan siswa.

Penilaian setiap aspek yang diamati menggunakan skala likert 1-5 dengan rentang kategori dapat dilihat dari tabel dibawah:

Tabel 1. Rentang kategori skor aktivitas guru

\begin{tabular}{ccc}
\hline Aspek yang diamati & Skor & Kategori \\
\hline & $43-50$ & Sangat Baik \\
& $35-42$ & Baik \\
Aktivitas guru & $27-34$ & Cukup \\
& $19-26$ & Kurang \\
& $10-18$ & Sangat kurang \\
\hline
\end{tabular}

Tabel 2. Rentang kategori skor aktivitas siswa

\begin{tabular}{ccc}
\hline Aspek yang diamati & Skor & Kategori \\
\hline & $43-50$ & Sangat Baik \\
Aktivitas guru & $35-42$ & Baik \\
& $27-34$ & Cukup \\
& $19-26$ & Kurang \\
& $10-18$ & Sangat kurang \\
\hline
\end{tabular}


Tabel 3. Rentang kategori kemampuan berpikir kritis siswa

\begin{tabular}{ccc}
\hline Aspek yang diamati & Skor & Kategori \\
\hline & $9,7-12$ & Sangat Kritis \\
Kemampuan berpikir kritis & $7,3-9,6$ & Kritis \\
& $4,9-7,2$ & Cukup Kritis \\
& $2,5-4,8$ & Kurang Kritis \\
& $0-2,4$ & Tidak Kritis \\
\hline
\end{tabular}

Tabel 4. Rentang persentase hasil belajar kognitif

\begin{tabular}{ccc}
\hline Aspek yang diamati & Skor & Kategori \\
\hline & $92-100$ & Sangat Baik \\
Hasil belajar kognitif & $84-91$ & Baik \\
& $75-83$ & Cukup Baik \\
& $>75$ & Kurang Baik \\
\hline
\end{tabular}

Tabel 5. Klasifikasi persentase capaian LKS

\begin{tabular}{ccc}
\hline Aspek yang diamati & Skor & Kategori \\
\hline & $84-100$ & Sangat Tinggi \\
Lembar kerja siswa & $68-83$ & Tinggi \\
& $52-67$ & Sedang \\
& $36-51$ & Rendah \\
& $20-35$ & Sangat Rendah \\
\hline
\end{tabular}

\section{HASIL PENELITIAN DAN PEMBAHASAN}

Aktivitas Guru

Salah satu tujuan penelitian ini adalah meningkatkan aktivitas guru dalam pembelajaran menggunakan pendekatan pembelajaran problem posing berorientasi HOTS. Aktivitas guru yang diamati setiap pertemuan yaitu: (1) mengucapkan salam, membuka pelajaran, dan mempersiapkan siswa belajar, (2) mengingatkan materi yang akan dipelajari, (3) memberikan apersepsi dan motivasi di awal pembelajaran, (4) menjelaskan materi pembelajaran, (5) mengorganisir siswa dalam kelompok, (6) membimbing siswa dalam mengajukan dan menjawab soal, (7) membimbing siswa dalam memecahkan masalah yang didapat dari kelompok lain, (8) membimbing siswa menyimpulkan materi pelajaran, (9) memberikan tugas, (10) menginformasikan materi selanjutnya dan meminta siswa mempelajari di rumah. Hasil observasi peningkatan aktivitas guru pada siklus I dan siklus II dapat dilihat pada Gambar 1.

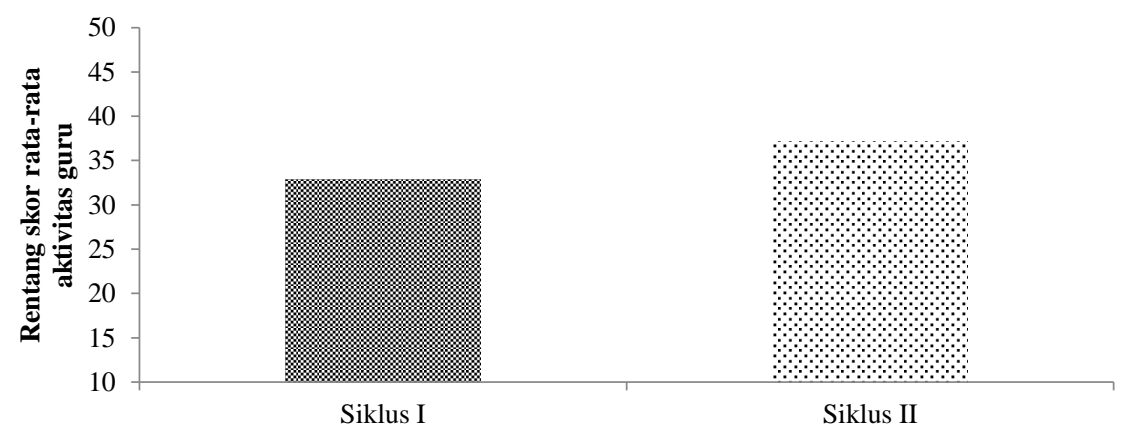

Gambar 1. Perbandingan skor aktivitas guru setiap siklus 
Pada siklus I pertemuan pertama, aktivitas guru terdapat kekurangan dalam menjelaskan materi pada bagian saat menjelaskan materi memakan waktu yang sedikit lebih lama karena masih ada siswa yang belum terkondisikan. Saat membimbing/mendorong siswa dalam membuat soal yang sesuai materi, menjawab soal yang telah dibuat, dan menjawab soal yang diperoleh dari kelompok lain. Guru masih kurang dalam tahap membimbing siswa sehingga siswa terlihat bingung dengan tahapan yang belum pernah mereka temukan pada pembelajaran sebelumnya. Guru sebelumnya hanya menjelaskan pendekatan problem posing tidak memberi contoh terlebih dahulu. Pada siklus I pertemuan kedua guru mulai memperbaiki kekurangankekurangan yang ada pada pertemuan pertama dan mengikuti saran-saran yang diberikan oleh observer. Guru menjelaskan materi pembelajaran disertai dengan beberapa contoh soal. Saat memberikan penjelasan guru lebih sering meminta siswa untuk lebih fokus agar guru tidak mengulang-ulang penjelasan. Guru juga lebih mengoptimalkan siswa dalam hal melakukan diskusi kelompok agar waktu dapat digunakan dengan efisien dan juga berusaha mengaktifkan siswa yang pasif, dengan begitu dapat menimbulkan aktivitas siswa yang baik dalam hal berpikir untuk dapat memecahkan masalah dan berbuat atau bersikap terhadap kelompoknya dalam hal berdiskusi sehingga siswa akan memperoleh pengetahuan yang baik. Hal ini sejalan dengan pendapat Suryosubroto (2009) bahwa guru sangat berperan dalam pengelolaan kelas. Jika guru mampu mengelola kelasnya dengan baik, maka tidaklah sukar bagi guru untuk mencapai tujuan yang dirumuskan. Kekurangan aktivitas guru dalam pembelajaran di siklus I diperbaiki pada siklus berikutnya yaitu siklus II.

Pada siklus II , terlihat adanya kemajuan aktivitas guru dalam melaksanakan kegiatan pembelajaran. Guru terlihat dapat menjelaskan materi dengan baik disertai dengan contoh soal, lebih dapat menertibkan siswa pada saat diskusi kelompok dan guru dapat lebih mengefisiensikan waktu. Guru menekankan kepada siswa harus terlibat aktif dalam kelompok karena dengan berkelompok siswa akan bekerjasama dan akan bertanggung jawab terhadap satu sama lain untuk saling memahami dan sama-sama saling belajar untuk mengerti materi pembelajaran yang diajarkan oleh guru. Hal ini sesuai dengan pendapat Dooly (2008) bahwa siswa dalam pembelajaran yang bersifat kolaboratif akan bertanggung jawab terhadap satu sama lain dalam pembelajaran dan mencapai tujuan bersama dimana siswa saling membantu anggota kelompk agar mengerti dan belajar.

\footnotetext{
Aktivitas Siswa

Aktivitas siswa yang diamati yaitu (1) menjawab salam, berdoa dan menanggapi ketika guru memeriksa kehadiran, (2) merespon apersepsi dan motivasi yang diberikan guru, (3) mendengarkan tujuan pembelajaran (4) memperhatikan penjelasan guru, (5) membentuk kelompok, (6) berdiskusi dalam mengajukan pertanyaan, (7) menjawab pertanyaan dari soal yang diajukan, (8) menerapkan strategi untuk memecahkan masalah yang dibuat kelompok lain, (9) mempersentasikan hasil diskusi, (10) menyimpulkan materi pelajaran. Hasil pengamatan aktivitas siswa pada setiap siklus dapat dilihat pada Gambar 2.
} 


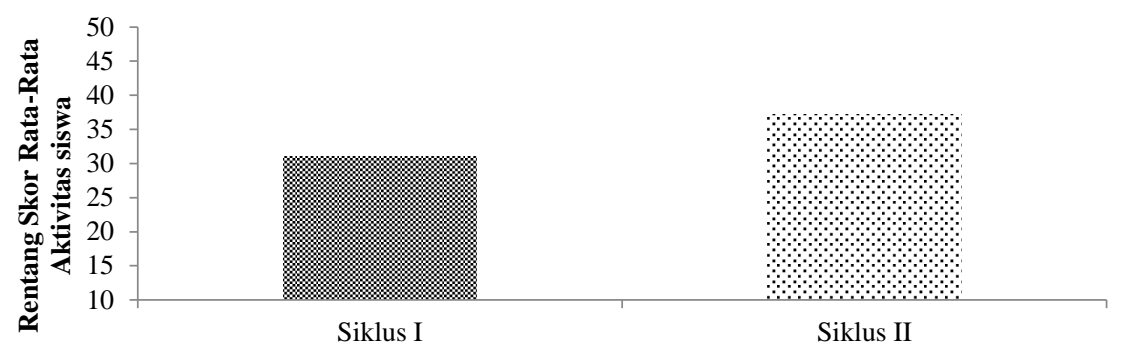

Gambar 2. Perbandingan skor rata-rata aktivitas siswa setiap siklus

Proses pembelajaran pada siklus I aktivitas siswa berada pada kategori cukup aktif dengan skor rata-rata 28,75. Aktivitas siswa berada pada kategori cukup dikarenakan beberapa hal yaitu siswa merasa kurang termotivasi untuk belajar dengan problem posing berorientasi HOTS, siswa masih belum bisa memahami materi yang dijelaskan guru, siswa belum terlibat aktif dalam diskusi kelompok, siswa masih belum terbiasa mempresentasikan hasil diskusinya di depan kelas. Keadaan tersebut dapat terjadi karena guru belum bisa memotivasi siswa secara penuh untuk terlibat dan berpartisipasi aktif dalam proses pembelajaran sehingga perlunya perbaikan dari guru untuk mengajak siswa berpartisipasi aktif dalam pembelajaran agar siswa dapat menemukan konsep yang akan ditemukan selama proses belajar.

Pada siklus II aktivitas siswa berada pada kategori aktif dengan skor rata-rata dari hasil penilaian observer sebesar 37,75. Berdasarkan hasil perhitungan penilaian observer pada siklus II aktivitas siswa pada proses belajar mengajar menggunakan problem posing berorientasi HOTS pada siklus ini mengalami peningkatan karena adanya perbaikan dalam mengajar guru yang mempengaruhi aktivitas siswa sehingga pada siklus II mengalami peningkatan. Dengan menjelaskan materi secara rinci beserta contoh soal, siswa dapat membuat soal HOTS dan menjawabnya dan juga karena sudah terbiasa membuat soal pada pertemuan disiklus I. Siswa lebih aktif berdialog dan mengeluarkan pendapat saat kegiatan diskusi berlangsung karena guru lebih mengupayakan agar siswa yang terlihat pasif dapat ikut berpartisipasi dalam proses pembelajaran yang diterapkan guru. Suasana dalam pembelajaran problem posing berorientasi HOTS menuntut siswa aktif selama pembelajaran berlangsung, yaitu aktif untuk membuat dan menjawab soal HOTS, serta menjawab soal yang diperoleh dari kelompok lain, aktif berinteraksi dengan kelompok lain melalui kegiatan diskusi kelompok maupun diskusi kelas, dan mempresentasikan di depan kelas.

Pada proses pembelajaran dari siklus I ke siklus II. Terdapat kenaikan skor rata-rata dari siklus I ke siklus II yaitu sebesar 6,12. Terjadinya peningkatan aktivitas siswa karena pada siklus II siswa sudah mulai terbiasa dengan kegiatan pembelajaran yang diterapkan. Siswa lebih aktif dalam kegiatan pembelajaran dan termotivasi dalam membuat soal HOTS dan dalam mempersentasikan hasil diskusi kelompoknya.

\section{Lembar Kerja Siswa (LKS)}

LKS yang dinilai setiap pertemuannya meliputi 3 aspek, yaitu (1) mengajukan pertanyan, (2) menyelesaikan pertanyaan yang diajukan, dan (3) menyelesaikan pertanyaan dari kelompok lain. Peningkatan skor rata-rata LKS setiap pertemuan yang diperoleh siswa dapat dilihat pada Gambar 3. 


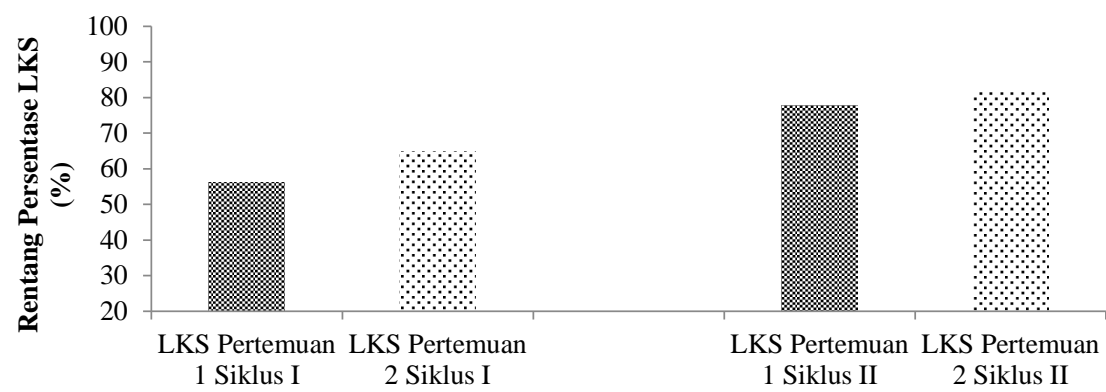

Gambar 3. Peningkatan skor LKS siswa pada setiap pertemuan

Pada LKS pertemuan pertama di siklus I indikator yang ingin dicapai yaitu menganalisis sifat larutan garam melalui percobaan. Berdasarkan materi dan percobaan yang dilakukan, sebagian siswa telah mampu mengajukan dan memecahkan soal namun pada pertemuan pertama tingkat kognitif soal yang diajukan siswa belum mencapai HOTS. Adapun hasil kemampuan siswa dalam mengajukan soal serta menyelesaikan soal yang diajukan dan soal yang didapat dari kelompok lain yaitu pada tahapan mengajukan soal sebesar $56,41 \%$, pada tahapan ini siswa belum mampu mengajukan soal HOTS dan mengajukan soal berdasarkan materi yang telah dijelaskan oleh guru.

Pada tahapan menjawab soal yang diajukan diperoleh skor sebesar $49,74 \%$ sama halnya dengan mengajukan soal, siswa belum mampu untuk menyelesaikan soal sesuai dengan soal yang diajukannya. Pada tahapan menyelesaikan soal yang didapat dari kelompok lain didapat skor yang diperoleh siswa sebesar 62,56\%. Pada tahap ini didapat skor paling tinggi dikarenakan sebagian kelompok siswa cukup mampu menyelesaikan soal dengan mencari sumber di buku dan di internet. Masing-masing kelompok termotivasi untuk menyelesaikan jawaban dari kelompok lain. Pada tahapan membuat dan menjawab soal siswa mengalami kesulitan karena belum memahami materi dengan baik dan mengalami kesulitan dalam membuat soal, hal ini dikarenakan siswa mengajukan soal berdasarkan materi dan data hasil percobaan, kelompok yang menjawab soal dengan kelompok yang membuat soal memiliki data hasil percobaan yang tidak sama ketika soal yang diajukan ditukar dengan kelompok lain, sehingga terjadi kesalahan ketika menyelesaikan soal tersebut. Peran guru sangat dibutuhkan dalam hal ini, guru harus mampu membimbing siswa dalam membuat soal HOTS, berusaha meluruskan kekeliruan dan memberikan penguatan agar siswa tidak salah konsep.

Pada LKS pertemuan kedua di siklus I indikator yang ingin dicapai yaitu menentukan sifat dan jenis garam yang terhidrolisis dari persamaan reaksi ionisasi. Pada LKS pertemuan kedua proses penemuan konsep sendiri dengan problem posing berorientasi HOTS melalui tahapan mengajukan soal, memecahkan soal, dan menyelesaikan soal yang didapat dari kelompok lain diperoleh masing-masing skor yaitu $67,17 \%, 57,43 \%$, dan 70,25\%, ini menunjukkan bahwa siswa mulai menguasai setiap tahapan problem posing. Namun pada pertemuan ini juga siswa belum mampu membuat soal HOTS dilihat dari persentase pengajuan soal. Pada tahapan menjawab soal yang diajukan masing-masing kelompok siswa menjawab soal tidak sesuai tahapan penyelesaian. Pada tahap menyelesaikan soal dari kelompok lain lain siswa termotivasi untuk menjawab dengan mencari sumber di internet.

Kemampuan siswa dalam melaksanakan tahapan- tahapan dari pembelajaran problem posing berorientasi HOTS siklus II ini $>75 \%$, ini berarti siswa sudah lebih memahami dan mampu menggunakan tahapan model pembelajaran problem posing 
berorientasi HOTS. Pada tahap membuat soal diperoleh persentase paling tinggi karena pada tahapan ini terdapat 2 kelompok yang mampu membuat soal HOTS. Pada tahapan menjawab soal yang mereka ajukan siswa sudah mampu menjawab soal karena soal sudah benar hingga mereka dengan mudah menjawab soal tersebut. Pada proses pengerjaan LKS pada tahapan membuat soal HOTS guru membimbing siswa dalam membuat soal HOTS, sehingga pada pertemuan ini juga terdapat 2 kelompok mampu membuat soal HOTS. Setiap pertemuan persentase nilai LKS siswa meningkat karena siswa memahami materi dengan baik sehingga mampu membuat dan menjawab soal HOTS dengan bimbingan guru.

\section{Kemampuan berpikir kritis}

Kemampuan berpikir kritis siswa secara keseluruhan pada siklus I dan siklus II terjadi peningkatan, kemampuan berpikir kritis siswa pada siklus I dengan kategori cukup kritis dengan skor rata-rata sebesar 6,99, sedangkan pada siklus II dengan kategori kritis dengan skor rata-rata sebesar 8,6. Rincian peningkatan kemampuan berpikir kritis siswa siklus I dan siklus II dapat dilihat pada Gambar 4.

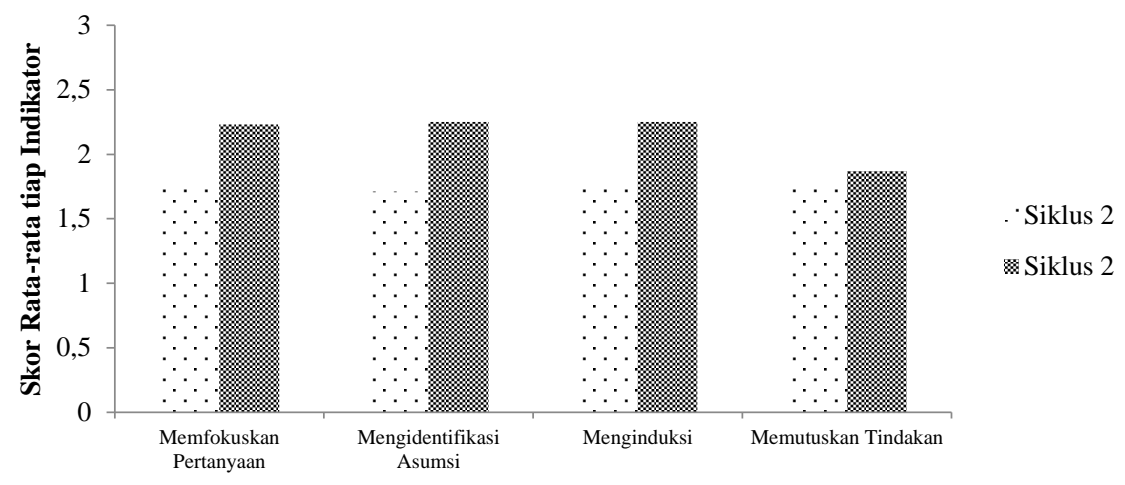

Gambar 4. Perbandingan skor rata-rata indikator berpikir kritis siswa setiap siklus

Indikator 1 pada tes siklus I, siswa kurang tepat dalam memberikan fokus permasalahan. Hal ini menunjukkan siswa belum memahami fokus permasalahan yang diminta pada soal. Pada siklus II terjadi peningkatan pada indikator ini, hal tersebut dapat dilihat dari hasil evaluasi di mana sebagian besar siswa telah mampu mencapai skor 3, ini berarti siswa dapat memberikan fokus permasalahan yang disajikan pada soal. Peningkatan kemampuan berpikir kritis pada indikator ini karena pendekatan problem posing merupakan sebuah pendekatan yang dapat mengembangkan kemampuan berpikir kritis, pada langkah-langkah pendekatan problem posing dalam proses pembelajaran membuat siswa dapat merumuskan suatu permasalahan dalam bentuk pertanyaan dan mencari solusi atas pertanyaan tersebut. Hal ini sejalan dengan pendapat Sani (2014) bahwa bahwa pembelajaran berbasis masalah dapat mengembangkan kemampuan berpikir tingkat tinggi (higher order thinking) yaitu berpikir kritis. Hal ini juga diperkuat oleh penelitian yang dilakukan oleh Palestina, Samingan dan Evi (2014) bahwa dengan pembelajaran berbasis masalah kemampuan berpikir kritis pada indikator memfokuskan pertanyaan meningkat dari hasil pretes dengan kategori kurang menjadi kategori sedang pada hasil postes.

Indikator 2 pada tes siklus I, siswa sudah cukup dapat mengidentifikasi asumsi yang ada pada soal tetapi tidak disertai dengan alasan. Hal ini menunjukkan 
siswa belum mengidentifikasi asumsi dengan memberikan alasan yang merunut. Pada siklus II terjadi peningkatan pada indikator ini. Hal tersebut dapat dilihat dari hasil evaluasi di mana sebagian besar siswa telah mampu mencapai skor 2-3. Ini berarti siswa dapat mengidentifikasi asumsi dengan memberikan alasan yang merunut meskipun belum lengkap. Banyak siswa sudah dapat mengidentifikasi suatu permasalahan, melalui proses pembelajaran berbasis masalah siswa dapat menemukan sendiri pengetahuan sehingga belajar menjadi bermakna. Hal ini sejalan dengan penelitian Palestina, dkk (2014) bahwa dengan pembelajaran pembelajaran berbasis masalah kemampuan berpikir kritis pada indikator mengidentifikasi asumsi kelas eksperimen lebih tinggi dibanding dengan kelas pembelajaran konvensional. Ini juga diperkuat oleh Sani (2014) bahwa pembelajaran berbasis masalah dapat mengembangkan berpikir tingkat tinggi (higher order thinking) yaitu berpikir kritis.

Indikator 3 pada tes siklus I dan siklus II, siswa sudah bisa menginduksi dari wacana yang diberikan pada soal. Hal tersebut dapat dilihat dari hasil evaluasi di mana sebagian besar siswa telah mampu mencapai skor 2-3, ini berarti siswa sudah benar dalam hal menyimpulkan secara deduksi. Meskipun pada siklus I masih ada sebagian siswa yang belum mampu menginduksi dengan benar, tetapi pada siklus II terjadi peningkatan siswa yang mendapat skor 0 dan 1 pada siklus I menjadi skor 2-3 pada siklus II. Peningkatan ini terjadi karena pada proses pembelajaran problem posing berorientasi HOTS dalam langkah tahapannya yaitu merumuskan permasalahan dalam bentuk pertanyaan soal HOTS. Hal ini sesuai dengan hasil penelitian Palestina, dkk (2014) yang menunjukkan bahwa terjadi peningkatan kemampuan berpikir kritis dikelas eksperimen melalui proses belajar dengan pembelajaran berbasis masalah pada indikator mengidentifikasi asumsi, menginduksi, menginduksi dan argumentasi.

Indikator 4 pada tes siklus I, siswa memberikan sebuah tindakan tetapi tidak dengan alasan yang lengkap. Hal ini menunjukkan siswa belum dapat memberikan alasan yang merunut untuk sebuah solusi pemecahan masalah. Pada siklus II terjadi peningkatan pada indikator ini. Hal tersebut dapat dilihat dari hasil evaluasi di mana beberapa siswa telah mampu mencapai skor 2-3. Ini berarti siswa sudah benar dalam hal menentukan suatu tindakan. Peningkatan ini karena kegiatan diskusi kelompok dalam hal membuat dan menjawab soal diduga memberi dampak yang cukup besar dalam mengembangkan kemampuan pada sub indikator menentukan suatu tindakan.

Kemampuan seseorang dalam menyelesaikan masalah yang dihadapi dalam kehidupannya, tidaklah dengan mudah dapat memperoleh penyelesaiaan tanpa proses belajar. Dari pemaparan diatas dapat disimpulkan bahwa pembelajaran dengan pendekatan problem posing berorientasi HOTS dapat meningkatkan kemampuan berpikir kritis pada indikator memfokuskan pertanyaan, mengidentifikasi asumsi, menginduksi dan menentukan suatu tindakan. Hal ini sejalan dengan penelitian Anto, dkk (2013) dalam penelitiannya dengan penerapan pembelajaran problem posing dapat meningkatkan keterampilan berpikir kritis siswa dan juga penelitian Setyorini, Sukiswo dan Subali (2011) bahwa model pembelajaran berbasis masalah dapat dijadikan solusi untuk meningkatkan kemampuan berpikir kritis siswa.

\section{Hasil belajar kognitif}

Berdasarkan hasil tes siklus I dan siklus II, dapat diketahui bahwa ketuntasan klasikal hasil belajar siswa meningkat sebesar $46,15 \%$ yang tersaji pada Gambar 5 


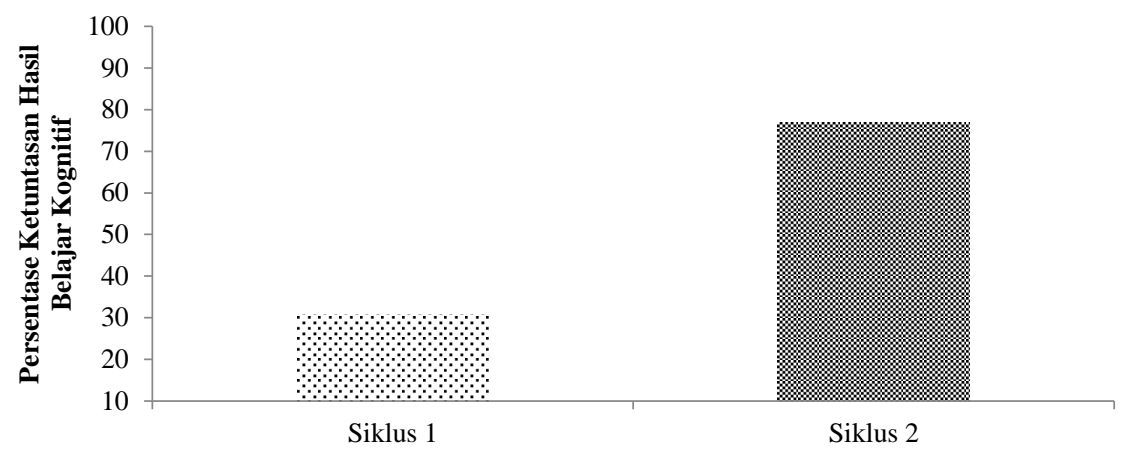

\section{Gambar 5. Perbandingan persentase ketuntasan klasikal hasil belajar setiap siklus}

Pada siklus I Indikator 1 berisi materi tentang membedakan jenis garam dari berbagai reaksi dengan alat penguji lakmus merah dan biru. Hasil rerata yang diperoleh $69,87 \%$ dalam kategori kurang baik menunjukkan bahwa hampir seluruh siswa belum memahami materi tersebut untuk menjawab soal-soal yang berhubungan dengan indikator 1 ini. Hal ini karena tingkat kognitif soal pada indikator 1 yaitu C4, sehingga siswa cukup sulit untuk menjawab soal tersebut, dan hanya sebagian siswa yang mampu menjawab soal tersebut. Selain itu, pada saat kegiatan percobaan siswa cukup memperhatikan hasil percobaan dan mendengarkan penjelasan guru. Soal pada indikator 2 tentang unsur-unsur pembentuk jenis garam dari asam dan basa penyusunnya dalam berbagai larutan. Hasil rerata yang diperoleh $69,87 \%$ dalam kategori kurang baik menunjukkan bahwa siswa belum cukup mampu memahami soal yang diberikan yaitu seperti pada soal nomor 2, siswa dituntut untuk mengingat komponen asam dan basa pembentuk larutan garam berdasarkan pengamatan warna pada kertas lakmus. Selain itu juga karena soal ini berada pada tingkat kognitif C4, siswa harus menganalisis jawaban yang benar pada pilihan jawaban.

Indikator 3 tentang mengidentifikasi sifat asam dan basa larutan garam berdasarkan kekuatan asam basa pembentuknya. Hasil rerata yang diperoleh $68,26 \%$ dalam kategori kurang baik menunjukkan bahwa sebagian besar siswa belum mampu menjawab soal yang diberikan seperti pada soal nomor 3. Rendahnya persentase pada indikator ini karena siswa masih belum memiliki pemahaman yang baik tentang materi yang diajarkan karena soal ini berupa pemahaman siswa tentang komponen asam dan basa yang akan menghasilkan suatu larutan berupa sifat dari larutan dan juga karena tingkat kognitif soal ini yaitu C4-C5 sehingga siswa mengalami kesulitan dalam menganalisis dan menyimpulkan jawaban. Hal ini sejalan dengan penelitian Selvianti, dkk (2013) menyatakan pemahaman konsep siswa tentang materi asambasa yang telah dipelajari sebelumnya masih kurang, menyebabkan siswa kesulitan untuk menentukan asam dan basa penyusun garam serta kesulitan untuk menentukan kekuatan asam dan basa tersebut.

Indikator 4 tentang menentukan sifat garam yang terhidrolisis dari persamaan reaksi ionisasi. Hasil rerata yang diperoleh $69,87 \%$ dalam kategori kurang baik. Rendahnya persentase pada indikator ini karena siswa masih kurang mampu dalam menentukan sifat garam yang terhidrolisis dari persamaan ionisasi, berarti siswa kurang mampu dalam memahami reaksi asam atau basa yang mengalami hidrolisis dari hasil reaksi tersebut. Selain itu disebabkan siswa masih belum memahami konsep prasyarat asam-basa menurut Teori Bronsted-Lowry, sehingga sulit bagi siswa dalam menentukan sifat garam yang terhidrolisis dari persamaan reaksi ionisasi. 
Hasil persentase indikator 5 tentang menentukan jenis garam yang tidak dapat terhidrolisis, terhidrolisis parsial, dan terhidrolisis total adalah sebesar $62,82 \%$ dalam kategori kurang baik. Indikator ini memiliki persentase terendah antara indikator lainnya. Rendahnya persentase pada indikator ini karena siswa belum mampu menuliskan persamaan reaksi ionisasi dan mereaksikan larutan asam dan basa menjadi larutan garam. Menuliskan reaksi ionisasi merupakan suatu perencanaan atau langkah awal dalam menyelesaikan soal, sehingga jika siswa sudah salah dalam menuliskan persamaan reaksi ionisasi, maka siswa juga akan salah dalam menuliskan reaksi hidrolisis dan dalam penentuan jenis hidrolisisnya. Kegagalan siswa dalam menuliskan persamaan reaksi ionisasi ini karena dalam pembelajaran sebelumnya guru kurang memberikan contoh dan latihan serta tidak memberikan penjelasan di depan kelas. Kurang aktif dan kurang percaya dirinya siswa dalam mengajukan pertanyaan terhadap materi yang kurang dimengerti, juga membuat guru mengira seluruh siswa telah paham tentang konsep persamaan reaksi ionisasi tersebut.

Sebagian besar siswa masih belum mampu dalam menentukan jenis garam yang dapat terhidrolisis sebagian, terhidrolisis total dan tidak dapat terhidrolisis. Namun juga ada beberapa siswa yang sudah mampu. Hal ini karena siswa sudah mampu memahami materi-materi yang diajarkan pada indikator sebelumnya menghubungkannya dengan materi pada indikator 5 sehingga siswa dapat menjawab soal-soal yang berhubungan dengan menentukan larutan yang dapat terhidrolisis dan dan tidak dapat terhidrolisis, sedang siswa yang belum mampu tersebut karena siswa yang bersangkutan masih belum mampu memahami konsep yang diperoleh selama pembelajaran.

Pada siklus II soal pada indikator 1,2, dan 3 berupa soal perhitungan $\mathrm{pH}$ dari larutan garam, sehingga siswa diharuskan memahami konsep yang dipelajari dengan baik. Indikator 1 tentang menghitung $\mathrm{pH}$ dari larutan garam yang terhidrolisis dari reaksi asam kuat dan basa lemah, indikator 2 tentang menghitung jumlah larutan yang terhidrolisis dari reaksi asam lemah dan basa kuat dan indikator 3 tentang menghitung $\mathrm{pH}$ larutan garam yang terhidrolisis dari reaksi asam lemah dan basa lemah. Hasil persentase untuk indikator 1, 2, dan 3 masing-masing adalah $80,76 \%, 76,15 \%$, dan $75,64 \%$. Secara keseluruhan, siswa sudah mampu menerapkan dan memahami konsep pembelajaran dengan baik serta mampu memahami dan menerapkan rumus dalam perhitungan karena persentase keberhasilan tiap indikator tersebut dalam kategori cukup baik dan hanya beberapa siswa yang belum mampu menjawab soal.

Pada siklus II ini rata-rata hasil belajar dalam kategori cukup baik karena guru mengoptimalkan proses pembelajaran melalui pendekatan problem posing berorientasi HOTS dengan meningkatkan pemahaman siswa terhadap materi hidrolisis garam terutama dalam penggunaan rumus dan pengoperasian hitung matematika. Selain itu, pemberian latihan-latihan dan pembuatan soal HOTS oleh siswa dalam menyelesaikan perhitungan $\mathrm{pH}$ larutan garam meningkatkan kemampuan matematika siswa dalam menyelesaikan perhitungan $\mathrm{pH}$ larutan garam dengan benar dan tepat. Peningkatan hasil belajar kognitif HOTS siswa bukan hanya hasil dari upaya guru untuk memperbaiki kegiatan pembelajaran. Namun juga hasil yang diperoleh siswa itu sendiri sebagai upaya untuk memperbaiki pemahaman mereka terhadap materi pembelajaran. Siswa menjadi lebih aktif dalam memberi dan menerima masukan, mengelaborasi, mencari solusi, menggeneralisasi temuan dan karakter lainnya sehingga terjadi pembelajaran sosio-kognitif yang baik. (Widodo dan Kadarwati, 2013).

Melalui pembelajaran dengan pendekatan problem posing berorientasi HOTS ini maka pengajaran yang terpusat pada siswa menjadi lebih optimal, sebab jika siswa mampu memecahkan masalah atau soal yang sulit, hal itu membuat siswa 
bangga, senang dan terbentuk longterm memory. (Widodo dan Kadarwati, 2013). Pada saat proses pembelajaran ini siswa didorong untuk membuat dan menjawab soal HOTS. Dalam hal ini guru membimbing dan memberikan arahan kepada siswa yang merasa kesulitan dalam menemukan konsep, sehingga pada setiap tahap pembelajaran dapat terlaksana dengan baik. Perbaikan kualitas pembelajaran guru berhasil dengan memperhatikan pelaksanaan yang kurang optimal pada siklus I sehingga dapat meningkatkan hasil belajar kognitif siswa pada siklus II.

\section{SIMPULAN}

Kesimpulan dalam penelitian ini yakni terdapat peningkatan aktivitas guru dan siswa dalam pembelajaran menggunakan pendekatan problem posing berorientasi HOTS pada materi hidrolisis garam. Pendekatan problem posing berorientasi HOTS dapat meningkatkan kemampuan berpikir kritis siswa dan hasil belajar kognitif siswa.

\section{DAFTAR RUJUKAN}

Anto, A. A., Akhdinirwanto, R. W., \& Fatmaryanti, S. D. (2013). Pemanfaatan model pembelajaran problem posing untuk peningkatan keterampilan berpikir kritis siswa di SMP Negeri 27 Purworejo. Jurnal Radiasi, 2(1).

Bruce, J., Marsha, W., \& Emily C. (2009). Models of teaching: model-model pengajaran. yogyakarta: Pustaka Pelajar

Dolly, S. (2008). Constructing knowledge together: telecollaborative language learning. A guidebook to moderating intercultural collaboration online. Bern: Peter Lang

Mulyasa. (2009). Praktek penelitian tindakan kelas. Bandung: Remaja Rosdakarya

Nurina, D.L dan Retnawati, H. (2015). Keefektifan pembelajaran menggunakan pendekatan problem posing dan pendekatan open-ended Ditinjau Dari HOTS. Jurnal Pendidikan Matematika. 10(2).

Palestina, S.M.F., Samingan \& Evi, A. (2014). Penerapan pendekatan kemampuan berpikir kritis pada konsep sistem pernapasan manusia. Jurnal Biotik. 2(1). ISSN 2337-9812

Selvianti, Ramadani, dan Jusniar. (2013). Efektivitas metode pemecahan masalah untuk meningkatkan hasil belajar dan keterampilan generik sains siswa kelas XI IA 2 SMA Negeri 8 Makassar pada materi pokok hidrolisis garam. Jurnal Pendidikan Kimia ICP FMIPA Universitas Negeri Makassar.Vol. 14.No. 1.

Setyorini, U., S.E Sukiwo., dan B.Subali. (2011). Model pembelajaran berbasis masalah dapat meningkatkan kemampuan berpikir kritis siswa. Jurnal Pendidikan Fisika Indonesia. 7.52-56

Sudarman. (2007). Problem based learning: suatu model pembelajaran untuk mengembangkan dan meningkatkan kemampuan memecahkan masalah. Jurnal Pendidikan Inovatif. 2 (7).

Suharsimi, A, Suhardjono dan Supardi. (2015). Penelitian tindakan kelas. Jakarta: Bumi aksara.

Suryosubroto, B. (2009). Proses belajar mengajar di sekolah. Jakarta: Rinieka Cipta.

Widodo, T dan Kadarwati, S. (2013). Higher order thinking berbasis pemecahan masalah untuk meningkatkan hasil belajar berorientasi pembentukan karakter siswa.Cakrawala pendidikan. 32(1).

Widoyoko, E.P. (2016). Penilaian hasil pembelajaran di sekolah. Yogyakarta:Pustaka Pelajar. 